Jahangirnagar University J. Biol. Sci. 8(1): 35-44, 2019 (June)

\title{
Neuropharmacological and gastrointestinal evaluation of coloring agent metanil yellow used in food and beverages
}

\author{
Md. Arfanur Rahman, Arpon Krishna Bala, Md. Ataur Rahman, Md. Kamrul \\ Hasan and Runa Masuma* \\ Department of Pharmacy, Jahangirnagar University, Savar, Dhaka-1342, Bangladesh
}

\begin{abstract}
Metanil yellow as a coloring agent is widely used in food industry to make food more appealing, appetizing and informative. Regulatory organization like FDA maintains strict rules but in our country coloring agents are at randomly used. This study is designed to evaluate side effects of metanil yellow on central nervous system and gastrointestinal tract in mice. Open field, hole board and hole cross tests were done to evaluate the effects of central nervous system; while castor oil and magnesium sulfate induced diarrheal tests were done to observe the effects on gastrointestinal tract. The mice were administered a dose of $5 \mathrm{gm} / \mathrm{kg}$ body weight of metanil yellow considered as 1x dose (MTYx) and another dose of $20 \mathrm{gm} / \mathrm{kg}$ body weight of metanil yellow considered as $4 \mathrm{x}$ dose (MTY4x). In the study, the metanil yellow exhibited central nervous system stimulatory effects based on hole cross test $(p=000 * * *$, $\left.\mathrm{p}=.003^{* *}, \mathrm{p}=000^{* * *}, \mathrm{p}=.001^{* * *}\right)$, hole board test $\left(\mathrm{p}=.03^{*}, \mathrm{p}=.005^{* *}, \mathrm{p}=.041^{*}, \mathrm{p}=0.018^{*}\right)$, and open field test $\left(\mathrm{p}=0.004^{* *}, \mathrm{p}=.002^{* *}, \mathrm{p}=.002^{* *}, \mathrm{p}=.011^{*}, \mathrm{p}=0.008^{*}\right)$. On the other hand gastrointestinal test results failed to show a significant effect $(\mathrm{p}=.04 *)$.
\end{abstract}

Key word: Metanil yellow, central nervous system, gastrointestinal tract effect

\section{INTRODUCTION}

Coloring agent used in food and pharmaceutical products is of natural or synthetic origin. 'Metanil yellow' is a yellow azo dye and is used extensively as a food colorant. It has been classified under category CII by the Joint FAO/WHO Expert Committee for Food additives and available safety data is inadequate for evaluation. According to US, Food and Drug Administration, 'Metanil yellow' has been allowed for external use only [Color additive regulations, FDA, 2012].

Chemically 'Metanil yellow' is a sodium or calcium salt of [m-(p-anilinophenyl) azo] benzene sulfonic acid and is made from diazotized metanilic acid and diphenylamine (Srivastava et al., 1978; Ghosh et al., 2017). 'Metanil yellow' is highly-water-soluble and due to the presence of chemical azo group which is toxic in nature; this dye is not permitted for food materials. Therefore it is extensively used in the developing countries as a colorant for sweet meat, confectionary products, cereals, ice-creams and beverages (Gupta et al., 2003).

It is reported that 'Metanil yellow' alters hematopoietic system in rats and reduces mucin secretion from intestinal cells in them (Khanna \& Das, 1991). After oral administration,

\footnotetext{
*Corresponding author. E-mail: masuma@juniv.edu
} 
'Metanil yellow' may cause toxic methaemoglobinaemia and cyanosis in humans (Sachdeva et al., 1992) and also allergic dermatitis when it is in direct contact with the skin (Hausen, 1994). Metanil yellow also has tumor-inducing effects and may create intestinal and enzymatic disorders in the human body (Das et al., 1997). 'Metanil yellow' may cause normochromic macrocytic anemia and may markedly increase number of lymphocytes and monocytes in human (Prasad \& Rastogi, 1983).

Adulterations of food items with hazardous dyes impose adverse impacts on health. So long-term consumption of these adulterated food items become a challenge especially in developing and under developed countries (Nath et al., 2016; Sarkar \& Ghosh, 2012). In fact the use of non-permitted colors has major economic consequences on worldwide food industries as well as on public health and society. As 'Metanil yellow' is widely used in foods without safety concern, this study is designed to investigate the effects of this agent on central nervous system and gastrointestinal in mice.

\section{MATERIALS AND METHODS}

Source: 'Metanil yellow' was collected from local market of Dhaka, Bangladesh.

\section{Study Plan:}

a. Selection of animals: Female mice (Swiss-Webster strains, 25-35 gm body weight) were chosen for the study. Mice were given with food and tap water ad libitum and were maintained at constant room temperature $\left(22.0 \pm 1.0^{\circ} \mathrm{C}\right)$, humidity $55-65 \%$ and $12 \mathrm{~h}$ light / $12 \mathrm{~h}$ dark cycle. Mice were divided in several groups having 6-10 mice in each group. In each experiment, one group of mice was designated as 'Control' group where mice were given distilled water and the other group designated as 'Treated' group where mice were given 'Metanil yellow'.

b. Dose and route of administration: In this study each mice of treated group was given orally a dose of $5 \mathrm{gm} / \mathrm{kg}$ body weight of metanil yellow, considered as 1x dose (MTYx) and also another dose of $20 \mathrm{gm} / \mathrm{kg}$ body weight of metanil yellow considered as $4 \mathrm{x}$ dose (MTY4x).

\section{Test for evaluation}

\section{a. Central nervous system effect}

Hole cross test: A plastic partition plate was fixed in the middle of a cage $(30 \times 20 \times 14 \mathrm{~cm}$, in size). A hole ( $3 \mathrm{~cm}$ in dia), at a height of $7.5 \mathrm{~cm}$ was made in the center of the plate, so that the mice can pass through it. Later on the number of passing out of the mouse through that hole from one end of the cage to another for a period of 2 minutes at pre 30 min and post 30,60, 120 and 240 minutes after the oral administration of the test drug was recorded. Similarly records were kept for the control animals. The mice were kept in an isolated and noiseless condition as described by Takagi et al., 1971.

Hole board test: A total of 16 holes (each was $3 \mathrm{~cm}$ in dia), were presented to the mouse in a flat space of 25 square centimeters. Each mouse was transferred carefully to one 
corner of the field and was allowed it to pass the holes. Later on the number of ambulation (expressed as the number of holes passed) was recorded. Similarly head dipping and number of fecal boules excretion was recorded. In both cases records were kept for a period of 2 minutes at pre 30 minutes and post 30,60, 120 and 240 minutes intervals. Results were compared with the controls treated with distilled water (Nakama et al., 1972).

Open field: The floor of an open field of half square meter was divided into a series of squares, each alternatively was colored with black and white. The number of squares traveled by the test animal was recorded for a period of 2 minutes. The observation was conducted at pre 30 minutes and post 30, 60, 120, and 240 minutes intervals. Test results were compared with the results of control (Gupta et al., 1971).

\section{b. Gastrointestinal effect}

Castor oil induced diarrheal test: In this study Castrol oil induced diarrheal test was conducted according to the method as described by Niemeegeers et al., 1976 and Yegnanarayan \& Shrotri, 1982. Here mice weighing 25-30 g was given Castrol oil (0.5 $\mathrm{ml}$ ) p.o. and were observed carefully. Mice showing diarrhea were kept for further study. Drug pre-treatment was given orally 1 hour before the mice were administered with the standard dose of $0.5 \mathrm{ml}$ of Castor oil. The animals caged individually and examined for the presence of diarrhea on an hour basis for 6 hours after the Castor oil challenge. Diarrhea was defined as the presence in the stool of fluidy material, which stained the absorbent paper, placed beneath the cage. The number of respondents, the number of stools passed during the 6-hours period was noted for each mouse separately.

$\mathbf{M g S O}_{4}$ induced diarrheal test: Here the method as described by Zavala et al., 1998 was followed. Mice weighing 25-30 g was given $\mathrm{MgSO}_{4}$ (100 mg $\mathrm{MgSO}_{4} / 10 \mathrm{ml}$ water) p.o. and were observed carefully. Mice showing diarrhea were kept for further study. Drug pre-treatment was given orally 1 hour before the mice were administered with the standard dose of $1 \mathrm{ml}$ of magnesium sulfate. The animals were caged individually and examined for the presence of diarrhea on an hour basis every hour for 6 hours after the Magnesium sulfate challenge. The number of respondents, the number of stools passed during the 6-hour period was noted for each mouse separately.

Statistical Analysis: Experimental data were analyzed using SPSS Programme. Values were expressed as Mean \pm SEM (Standard Error of the Mean). Unpaired " $\mathrm{t}$ " tests and 5\% level of confidence were done as the test of significance (Daniel 1999; Glasnapp \& Poggio 1985; Hill \& Hill 1991; Mahajan 1997; Snedecor \& Cochran, 1973).

\section{RESULTS AND DISCUSSION}

Central nervous system test: Hole cross, hole board, and open field test were carried out to get a clear picture on the effect of the coloring agent under consideration on the pattern of behavior character by locomotion, spontaneous ambulatory activity, exploratory activity and emotional defecation of animals. 
In hole cross test, results showed that for $1 \mathrm{x}$ dose, there was no significant differences in locomotion compared to control group. On the other hand, for $4 \mathrm{x}$ dose, the control group which received distilled water showed no movement through the hole and for that reason control bar was not detected (Figure 1b). But the number of hole crosses were increased for $4 \mathrm{x}$ dose coloring agent treated mice compared to that of control group. The results were highly significant at $0,30,60,120$ and 240 minutes time periods $\left(\mathrm{p}=000^{* * *}, 003^{* *}\right.$, $000^{* * *}, 001^{* * *}$ and $000^{* * *}$ ) (Figure 1a and $1 \mathrm{~b}$ ).

\section{a. Hole cross (1x dose)}

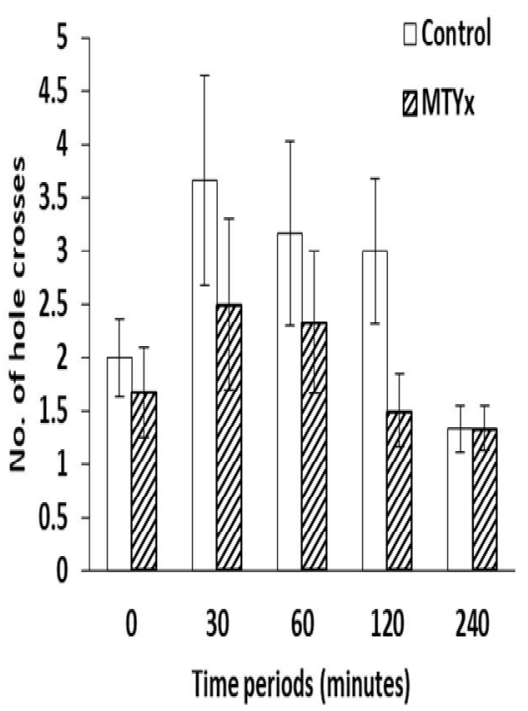

b. Hole cross (4x dose) [Control

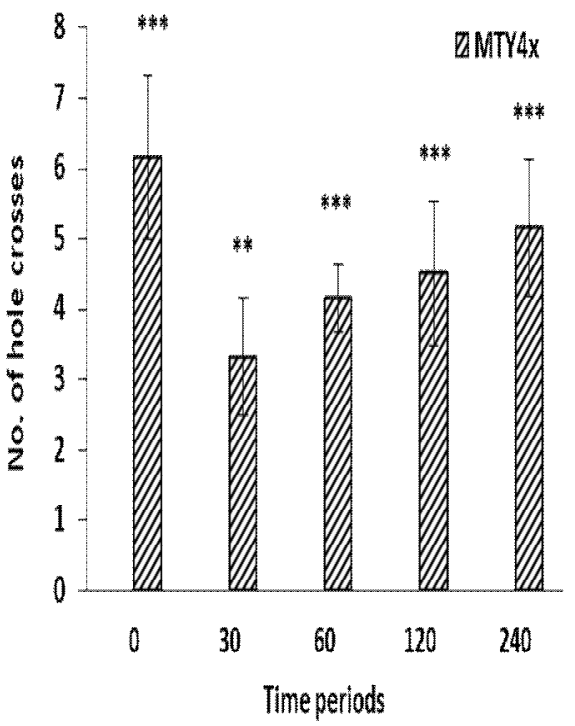

Fig. 1. Effect of Metanil yellow' a. MTYx and b. MTY4x dose on hole cross test in mice

In case of hole board ambulation test, administration of 'Metanil yellow' at lower dose (1x) showed a significant increase in ambulation at $0 \mathrm{~min}\left(\mathrm{p}=.030^{*}\right)$ and $60 \mathrm{~min}$ $\left(\mathrm{p}=.005^{* *}\right)$ time intervals compared to control. For $4 \mathrm{x}$ dose, ambulation was increased at each time interval. No significant results were observed except a significant increase at 0 min time period $\left(\mathrm{p}=.041^{*}\right)$ (Figure $2 \mathrm{a}$ and $2 \mathrm{~b}$ ). In hole board head dipping test, head dipping was decreased for $1 \mathrm{x}$ dose but was increased when it was $4 \mathrm{x}$ dose compared to control group. No significant differences were found in both cases (Figure 3a and 3b). 
a. Hole board Ambulation ( $1 x$ dose)

b. Hole board Ambulation ( $4 x$ dose)
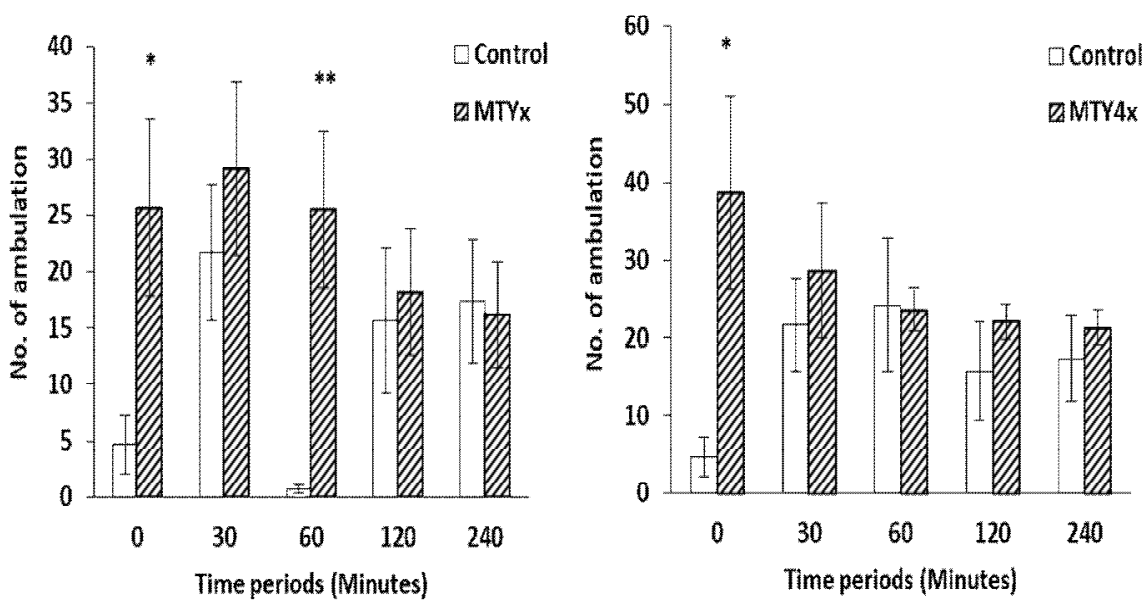

Fig. 2. Effect of 'Metanil yellow' a. MTYx and b. MTY4x doses on hole board ambulation test in mice

a. Hole board head dipping ( $1 \mathrm{x}$ dose)

b. Hole board head dipping ( $4 \mathrm{x}$ dose)
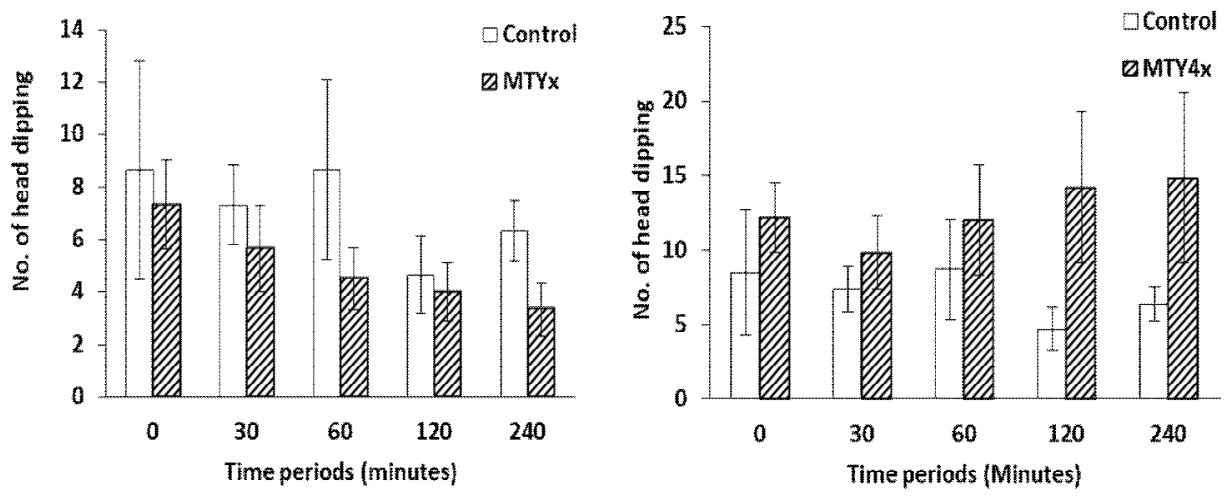

Fig. 3. Effect of 'Metanil yellow' a. MTYx and b. MTY4x doses on hole board head dipping test in mice

Results showed no change up to 240 minutes in case of hole board defecation when it was $1 \mathrm{x}$ dose but a significant reduction in defecation was observed $\left(\mathrm{p}=.018^{*}\right)$ during 240 minutes time period. Defecation was increased for $4 \mathrm{x}$ dose up to 240 minutes time period in comparison with the control group but the results were not significant (Figure $4 \mathrm{a}$ and $4 b)$. 
a. Hole board defecation ( $1 x$ dose)

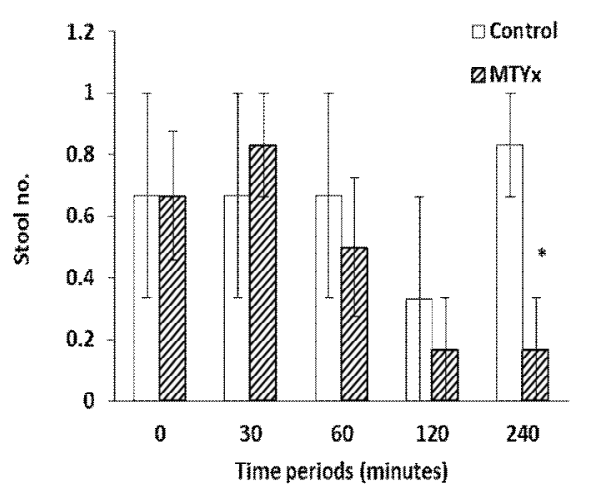

b. Hole board defecation ( $4 x$ dose)

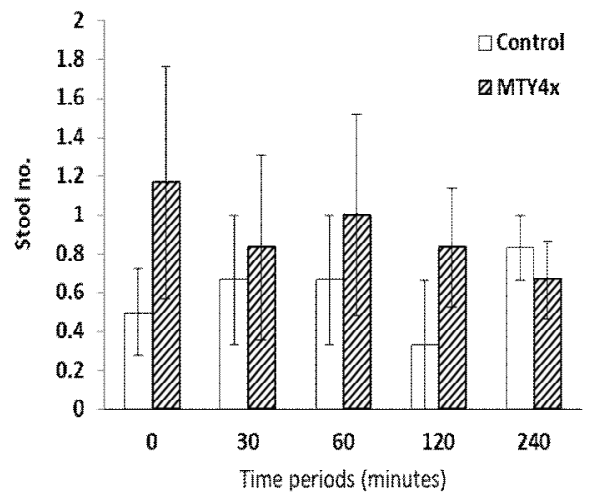

Fig. 4. Effect of 'Metanil yellow' a. MTYx and b. MTY4x doses on hole board defecation test in mice

Any centrally acting bioactive substance must have its effect on the normal behavior of the animals. The open field test was designed to assess the effect of such substance on the behavior activity on central nervous system of the animal. In case of open field test, experimental data showed a slight decreased in movement when it was $1 \mathrm{x}$ dose of coloring agent. Only the result of 240 minutes time period showed significant $\left(\mathrm{p}=0.004^{* *}\right)$ reduction of movement. After oral administration of higher $(4 \mathrm{x})$ dose of coloring agent, the movement decreased significantly at $30 \min \left(\mathrm{p}=0.004^{* *}\right), 60 \mathrm{~min}(\mathrm{p}=$ $\left.0.002^{* *}\right), 120 \min \left(\mathrm{p}=0.011^{*}\right)$ and $240 \mathrm{~min}\left(\mathrm{p}=0.008^{*}\right)$ time periods in comparison of control group (Figure 5a and $\mathrm{b}$ ).

\section{a. Open field movements (1x dose)}

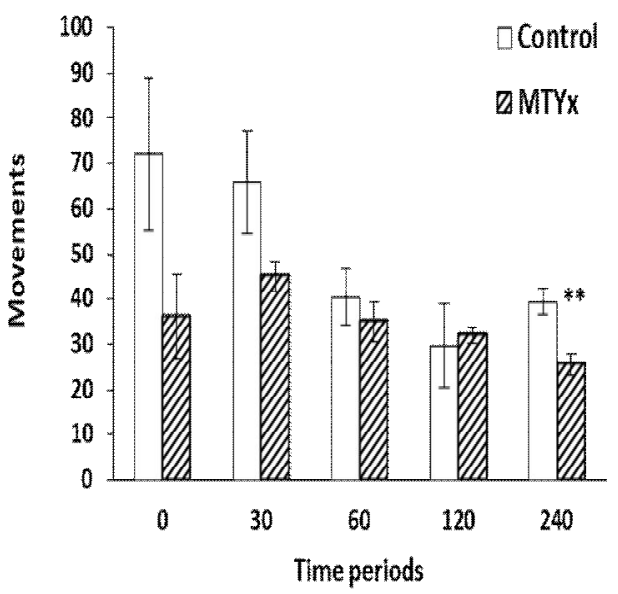

b. Open field movement ( $4 x$ dose)

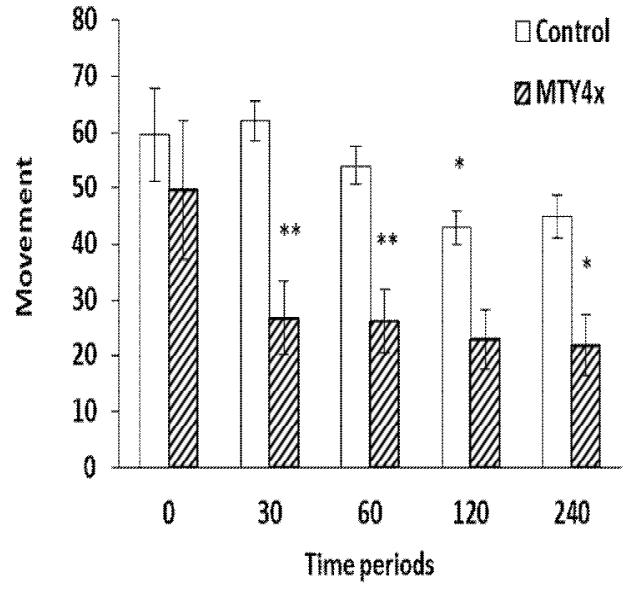

Fig. 5. Effect of 'Metanil yellow' a. MTYx and b. MTY4x doses on open field test in mice 
Therefore, the result of neuropharmacological tests demonstrated that 'Metanil yellow' has profound CNS stimulant activity at a higher dose in mice.

Result for Gastrointestinal effects: Castor oil induced diarrheal test was performed to investigate whether 'Metanil yellow' have any effect on the pattern of defecation on the diarrheal model of experimental mice. For $1 \mathrm{x}$ dose, the result showed an increased in the incident and severity of diarrhea at all time period except 5 hours. 'Metanil yellow' also increased the fecal content at 1 hour, 4 hour, 5 hour and 6 hour time period without any significant result when given at $4 \mathrm{x}$ dose. Significant reduction of defecation at 2 hour $(\mathrm{p}=.04 *)$ time interval was also found for $4 \mathrm{x}$ dose (Table 1$)$.

Table 1. Effects of 'Metanil yellow' (MTYx and MTY4x doses) on the castor oil induced diarrheal test in mice

\begin{tabular}{c|cccccccc}
\hline \multirow{2}{*}{ GROUP } & \multicolumn{7}{|c}{ No of Defecation (Mean \pm SEM) } \\
\cline { 2 - 7 } & $1 \mathrm{hr}$ & $2 \mathrm{hr}$ & $3 \mathrm{hr}$ & $4 \mathrm{hr}$ & $5 \mathrm{hr}$ & $6 \mathrm{hr}$ \\
\hline Control & $6.500 \pm 2.513$ & $4.167 \pm 1.448$ & $2.333 \pm .6147$ & $1.333 \pm .333$ & $2.000 \pm 1.212$ & $.500 \pm .224$ \\
MTYx & $7.333 \pm 1.994$ & $4.500 \pm .7189$ & $2.333 \pm .422$ & $1.500 \pm .619$ & $.667 \pm .333$ & $.833 \pm .167$ \\
t/p & $-.260 / .801$ & $-.206 / .842$ & $.000 / 1.000$ & $-.237 / .819$ & $1.061 / .331$ & $-1.195 / .262$ \\
Control & $2.000 \pm 1.000$ & $9.167 \pm 1.721$ & $2.500 \pm .429$ & $1.167 \pm .401$ & $.833 \pm .167$ & $.333 \pm .210$ \\
MTY4x & $3.500 \pm 1.025$ & $4.500 \pm .807$ & $1.333 \pm .422$ & $1.333 \pm .421$ & $1.167 \pm .167$ & $.500 \pm .223$ \\
t/p & $-1.048 / .319$ & $2.456 / .043^{*}$ & $1.941 / .081$ & $-.286 / .781$ & $-1.414 / .188$ & $-.542 / .600$ \\
\hline
\end{tabular}

$\mathrm{p} \leq 0.05=*, \mathrm{p} \leq 0.01=* *, \mathrm{p} \leq 0.001=* * *$

In $\mathrm{MgSO}_{4}$ induced diarrheal test, at lower (1x) dose 'Metanil yellow' increased the number of fecal discharge in mice compared to the control group without providing any significant results. For $4 \mathrm{x}$ dose, 'Metanil yellow' showed an irregular pattern of defecation in the experimental mice (Table 2).

The result of gastrointestinal test revealed that 'Metanil yellow' at both lower and higher doses slightly enhanced diarrhea in test animal.

Table 2. Effects of 'Metanil yellow' (MTYx and MTY4x doses) on $\mathrm{MgSO}_{4}$ induced diarrheal test in mice

\begin{tabular}{|c|c|c|c|c|c|c|}
\hline \multirow[b]{2}{*}{ GROUP } & \multicolumn{6}{|c|}{ No of Defecation (Mean \pm SEM) } \\
\hline & $1 \mathrm{hr}$ & $2 \mathrm{hr}$ & $3 \mathrm{hr}$ & $4 \mathrm{hr}$ & $5 \mathrm{hr}$ & $6 \mathrm{hr}$ \\
\hline Control & $2.167 \pm .980$ & $3.167 \pm 1.077$ & $.667 \pm .333$ & $.833 \pm .401$ & $.833 \pm .307$ & $.500 \pm .223$ \\
\hline MTYx & $3.000 \pm .967$ & $1.500 \pm .763$ & $1.000 \pm .516$ & $1.667 \pm .843$ & $1.167 \pm .477$ & $.500 \pm .341$ \\
\hline $\mathrm{t} / \mathrm{p}$ & $-.605 / .558$ & $1.262 / .239$ & $-.542 / .601$ & $-.892 / .401$ & $-.587 / .572$ & $.000 / 1.000$ \\
\hline Control & $2.500 \pm .563$ & $1.500 \pm .670$ & $.500 \pm .341$ & $1.500 \pm .921$ & $.167 \pm .167$ & $.333 \pm .210$ \\
\hline MTY4x & $2.000 \pm .578$ & $1.500 \pm .806$ & $.667 \pm .333$ & $1.167 \pm .307$ & $.333 \pm .210$ & $.167 \pm .167$ \\
\hline $\mathrm{t} / \mathrm{p}$ & $.620 / .549$ & $.000 / 1.000$ & $-.349 / .734$ & $.343 / .743$ & $-.620 / .550$ & $.620 / .550$ \\
\hline
\end{tabular}


Central nervous system and gastrointestinal tests were conducted to testify whether metanil yellow has any effect on the CNS and gastrointestinal tract. 'Metanil yellow' showed stimulatory effect on central nervous system revealed by increased number of locomotion, ambulation, and emotional defecation. Various studies suggested that consumption of metanil yellow in food may affect our nervous system revealed by damaging adult or developing brain in Wistar rats. Long term administration of metanil yellow also causes histopathological changes in brain tissue of rats (Nagaraja \& Desiraju, 1993; Sarkar, 2013).

Castor oil and magnesium sulfate induced diarrheal test were performed to evaluate gastrointestinal effect. Castor oil causes diarrhea due to its active metabolite, ricilonic acid (Victoria et al., 2000; Park, 2000; Ammon et al. 1974) that stimulates the peristaltic activity in the small intestine, leading to the changes in the electrolyte permeability of the intestinal mucosa. Castrol oil stimulates the release of endogenous prostaglandins (Galvez et al., 1993). Magnesium sulfate $\left(\mathrm{MgSO}_{4}\right)$ stimulates gastrointestinal movement by increasing intestinal motility and acts as laxative. It may lead to intraluminal fluid and electrolyte accumulation (Pasricha, 2006). Metanil yellow increases defecation rate slightly in both castor and $\mathrm{MgSO}_{4}$ induced diarrheal test. Metanil yellow consumed through food enters digestive system and causes gastro-intestinal toxicity, hepatotoxicity and damages the intestine (Nagaraja \& Desiraju, 1993; Dome et al., 2017).

So the decision come from the study is that 'Metanil yellow' is detrimental for the experimental rats. Consistent use of this coloring agent can cause serious effect on CNS. Further study of 'Metanil yellow' is required to find out its toxic effect on human body. Use of 'Metanil yellow' as food additive should be prohibited.

Acknowledgement: Authors are thankful to Mr. Shafiqul Islam, Laboratory of Pharmacology and Toxicology, Department of Pharmacy, Jahangirnagar University, for his cooperation in taking care of Swiss albino mice during the experiment.

\section{REFERENCES}

Ammon, H.V., Thomas, P.J. and Phillips, S. 1974. Effect of the oleic acid and recinolic acid on net jejuna water and electrolyte movement, J. Clin. Invest. 53: 374-379.

Daniel, W.W. 1999. Biostatistics a foundation for analysis in the health sciences. 7 th edn. : John Wiley \& Sons Inc., New York; pp. 164-176.

Das, M., Ramchandani, S., Upreti, R.K. and Khanna, S.K. 1997. Metanil yellow: a bifunctional inducer of hepatic phase I and phase II xenobiotic-metabolizing enzymes, Food. Chem. Toxicol. 35(8): pp. 835-838.

Dome, R.N., Hazra, S., Ghosh, D. and Ghosh, S. 2017. Beneficial effects of ethanolic leaf extract of Coriandrum sativum on metanil yellow induced alteration in activity of catalase and level of lipid peroxidation in hercine cardiac tissue In vitro, Int. J. Pharm. Pharm. Sci. 9: pp. 203-209.

Galvez, J., Zavzuelo, A., Crespo, M.E., Lorente, M.D., Ocete, M.A. and Jimenez, J. 1993. Antidiarrhoeic activity of Euphorbia hirta extract and isolation of an active flavonoid constituent, Planta. Med. 59: pp. 333-336. 
Ghosh, D., Singha, P.S., Firdaus, S.B. and Ghosh, S. 2017. Metanil yellow: The toxic food colorant, Asian Pacific J. Health. Sci. 4(4): pp. 65-66.

Glasnapp, D.R. and Poggio, J.P. 1985. Essentials of statistical analysis for the behavioral sciences, Charles E. Merrill Publishing Company, London: p. 363.

Gupta, B.D., Dandiya, P.C. and Gupta, M.L. 1971. A psychopharmacological analysis of behavior in rat, Jpn. J. Pharmacol. 21: pp. 293-298.

Gupta, S., Sundarrajan, M. and Rao, K.V.K. 2003. Tumor promotion by metanil yellow and malachite green during rat hepatocarcinogenesis is associated with dysregulated expression of cell cycle regulatory proteins, Teratogen. Carcinogen. Mutagen. supplement 1: pp. 301-312.

Hausen, B.M. 1994. A case of allergic contact dermatitis due to metanil yellow, Contact Dermatitis. 31(2): pp. 117-118.

Hill, A.B. and Hill, I.D. 1991. Bradford Hill's principles of medical statistics. 12th edn. B. I. Publishing Pvt. Limited, New Delhi: pp. 121-123 and 148-153.

Khanna, S.K. and Das, M. 1991. Toxicity, carcinogenic potential and clinical epidemiological studies on dyes and dye intermediates, Indian J. Sci. Res. 50: pp. 965-974.

Mahajan, S.K. 1997. Methods in biostatistics for medical students and research workers, $6^{\text {th }}$ edn., Jaypee Brothers Medical Publishers (p) Ltd, New Dehli: pp. 115-155.

Nagaraja, T.N. and Desiraju, T. 1993. Effects of chronic consumption of metanil yellow by developing and adult rats on brain regional levels of noradrenaline, dopamine and serotonin, on acetylcholine esterase activity and on operant conditioning, Food. Chem. Toxicol. 31: pp. 41-44.

Nakama, M., Ochiai, T. and Kowa, Y. 1972. Effects of psychotropic drugs on emotional behavior of naïve rats in Holed Open Field, Jpn. J. Pharmacol. 22: pp. 767-775.

Nath, P.P., Sarkar, K., Mondal, M. and Paul, G. 2016. Metanil yellow impairs the estrous cycle physiology and ovarian folliculogenesis in female rats, Environ. Toxicol. 31: pp. 2057-2067.

Niemeegeers, C.J.E., Lenaerts, F.M. and Aouters, F. 1976. Antidiarrhoeal drug, Van Baver W. and Lal H. (Eds.), Marcel Dekker, New York: pp. 65-114.

Park, K. 2000. Park's Textbook preventive and social medicine. M/S Banarsidas Bharat Publishers, Jabalpur, India.

Pasricha, P.J. 2006. Goodman \& Gillman's The Pharmacological Basis of Therapeutics. $11^{\text {th }}$ Edn, Treatment of Disorder of Bowel Motility and Water Flux; Anti-Emetics; Agents Used in Biliary and Pancreatic Disease. Part one, MacGRAW-HILL Publishers, New York; Ch37: p-992.

Prasad, O.M. and Rsstogi, P.G. 1983. Heamatological changes induced by feeding a common food colour, metanil yellow in Albino mice, Toxicol. Lett. 16: pp. 103-107.

Sachdeva, S.M. Mani, K.V., Adaval, S.K., Jalpota, Y.P., Rasela, K.C. and Chadha, D.S. 1992. Acquired toxic methaemoglobinaemia, The J. Assoc. Physicians Ind. 40(4): pp. 239240.

Sarkar, R. and Ghosh, A.R. 2012. Metanil yellow-an azo dye induced histopathological and ultrastructural changes in albino rat (Rattus norvegicus), Bioscan. 7: pp. 427-432.

Sarkar, R. 2013. Histopathological changes in the brain of metanil yellow treated albino rat (Rattus norvegicus), Int. J. Basic. App. Med. Sci. 3: 256-8.

Snedecor, G.W. and Cochran, W.G. 1973. Statistical methods. 6th edn. Lowa: The Iowa State University Press, Lowa: pp. 91-119.

Srivastava, L.P., Khanna, S.K. and Singh, G.B. 1978. Spectrophotometric estimation of metanil yellow in food stuffs, Intern. J. Environ. Anal. Chem. 5: pp. 119-124. 
Takagi, K., Watanabe, M. and Saito H. 1971. Studies on the spontaneous movement of animals by the hole cross test, Effect of 2-dimethylaminoethan, its acylesters on the central nervous system, Jpn. J. Pharmacol. 21: pp. 797- 810.

Victoria, C., Bryce, J., Fontaine, O. and Monasc, R. 2000 Reducing deaths from diarrhoea through oral rehydration therapy, Bulletin of World Health Organization, 78 (1): pp. 1246-1255.

Yegnanarayan, R. and Shrotri, D.S. 1982. Comparision of antidiarrhoel activity of some drugs in experimental diarrhea, Indian J. Pharmacol. 14(4): p. 293.

Zaval, M.A., Perez. S., Perez. C. and Vargas, R. 1998. Antidiarrhoeal activity of Waltheria americana, Commelina coelestis and lternanthera repens, J. Ethnopharmacol. 61: pp. 41-47. 